\title{
Cold Sterilization of Coconut Water Using Membrane Filtration: Effect of Membrane Property and Operating Condition
}

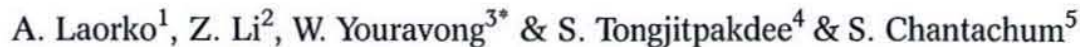 \\ ${ }^{1,3 \& 5}$ Department of Food Technology, Faculty of Agro-Industry \\ ${ }^{1,283}$ Membrane Science and Technology Research Center, Prince of Songkla University Hat Yai, Songkhla, \\ 90112,Thailand \\ ${ }^{4}$ Department of Food science and Technology, Faculty of Agro-Industry, Kasetsart University, \\ Bangkok,10900,Thailand
}

\begin{abstract}
Coconut water has been considered as a nutritional, refreshing and highly isotonic beverage with delicate aroma and flavor. In food sterilization technique, thermal processing, however tends to reduce these beneficial properties especially estrogen hormone and flavor. To overcome this limitation, this study therefore aimed to clarified and sterilized coconut water using non-thermal processing, membrane filtration. Hollow fiber microfiltration (MF) membrane with pore size of 0.1 and $0.2 \mu \mathrm{m}$ and ultrafiltration (UF) membrane with molecular weight cut-off (MWCO) of 100 and $30 \mathrm{kDa}$ were used. The effect of membrane pore size and MWCO on quality of clarified juice, permeate flux and fouling were studied. It was found that fresh coconut water and clarified coconut water obtained from MF and UF did not show difference in $\mathrm{pH}$, total soluble solid, reducing sugar, estrogen hormone and minerals including calcium, magnesium, phosphorus, potassium and sodium. The results from microbiological analysis of the clarified coconut water showed that sterilized of coconut water was obtained using either MF or UF membranes. This microbiological quality of clarified coconut water was met the Thai legislation for juice and drinks. The permeate flux of MF was much higher than those of UF while the fouling resistance of UF membrane was much higher than those of MF membrane. The permeate flux of membrane with pore size of $0.1 \mu \mathrm{m}$ was slightly lower than that of membrane with pore size of $0.2 \mu \mathrm{m}$. The results also indicated that the major fouling of both MF and UF membranes was reversible. The irreversible fouling resistance of $0.1 \mu \mathrm{m}$ membrane was the lowest and most of this irreversible fouling was external irreversible fouling, formed on the membrane surface. According to these results, it could be concluded that $0.1 \mu \mathrm{m}$ membrane was the most suitable membrane for clarification and sterilization of coconut water. In addition, the effects of TMP, cross flow velocity (CFV) and the \% recovery on permeate flux in batch concentration mode were also studied. It was found that the permeate flux of $0.1 \mu \mathrm{m}$ membrane was significantly increased with increasing $\mathrm{CFV}$ and decreased as \% recovery increased. These results suggested that permeate flux during MF of coconut water was dependent on reversible fouling and could be improved by using hydrodynamic modification techniques.
\end{abstract}

Keyzords: Coconut water, estrogen hormone, microfiltration, sterilization, ultrafiltration

\subsection{INTRODUCTION}

Thailand is one of the biggest producers of both fresh and processed coconut water in the world.

* Correspondence to:W. Youravong (email: wirote.y@psu.ac.th)
Nowadays, coconut water is becoming more widely consumed because of its beneficial health properties, naturally fat-free and low in food energy [1]. Coconut water contains many active compounds which have different therapeutic properties. It is non-allergenic and readily 
accepted by the body. Coconut water contains a complex of vitamins and minerals. It is high in potassium, chloride, calcium and magnesium. It is also highly recommended as a means for oral rehydration. Athletes and sports enthusiasts use coconut water to replenish electrolytes lost in perspiration. It works ever better than some popular commercial sports drinks [2]. Moreover, coconut water has been successfully used as liquid in intravenous therapy in emergency situations. Furthermore, coconut water has got many medicinal properties such as estrogen hormone especially estradiol ( $17 \beta$-estradiol) that improves synapse formation on dendritic spines in the hippocampus of oophorectomized rats. Estrogen also may improve cerebral blood flow and glùcose metabolism and it may in some way acts as an antioxidant [3]. Estrogen like hormone in coconut water also has an antagonistic effect with endogenous estradiol by competing for estrogen receptor [4].

The conventional process for fruit juice production involves the used of heat treatment to improve microbiological quality and extend the shelf life. However, nutritional and sensorial of the products are significantly affected. Since most of antioxidant, some nutritional components and flavor in fruit juice are not heat tolerant therefore it is reduced significantly after heat treatment [5]. To overcome this problem the new or suitable technologies with gentle heat treatment should be employed to preserve such properties. Membrane filtration is probably an alternative method to increase the shelf life and to reserve the peculiarity of fresh fruit such as color, aroma and nutritional quality. The aim of this study was to employ membrane filtration process to sterilized and clarified coconut water. To select the best membrane pore size or MWCO, the effect of membrane pore size and MWCO on permeate flux, fouling and quality of clarified coconut water including chemical, physical and microbiological properties, minerals and estrogen hormone content were studied. In addition, the effect of CFV, TMP in total recycle mode and \% recovery in batch concentration mode on permeate fluxes were also investigated.

\subsection{MATERIAL AND METHOD}

\subsection{Preparation of Coconut Water}

Young coconuts of 4-5 month old fruit from local farm in Songkhla province, Thailand were used through out this study. The coconut water obtained from the open nut fruit was collected in a clean container. After that it was filtrated though a cloth sheet to remove large solid particles which may block the inlet lumen of the hollow fiber membrane before introduced to the membrane system. The total soluble solid in the coconut water obtained was in the range of 5-7 ${ }^{\circ}$ Brix.

\subsection{Microflitration and Ultrafiltration Unit and Experiment}

The membrané system used was a hollow fiber module (Änersham Biosciences, UK) with a fiber diameter and length of $1 \mathrm{~mm}$ and $30 \mathrm{~cm}$ respectively. The membrane pore size and MWCO of the membranes were 0.1 and $0.2 \mu \mathrm{m}$ for MF and 30 and $100 \mathrm{kDa}$ for UF. The membrane system consisted of a 8 liter stainless steel jacketfeed tank, variable-feed pump (Leeson, USA) and transducers (MBS 3000, Danfoss, Denmark) for pressure of the feed, retentate and permeate measurement. The temperature of the feed was controlled by circulating cooling water through a jacket-feed tank. The CFV and TMP were controlled using needle permeate valve and variable speed-feed pump. The digital balance (GF-3000, A\&D, Japan), connecting the computer was used to measure the permeate flux.

In studying of the effect of membrane pore size and MWCO on quality of clarified juice, permeate flux and fouling, the experiments were carried out under total recycle mode (both retentate and permeate were returned to the feed tank) at constant CFV of $1.18 \mathrm{~m} / \mathrm{s}$, temperature of $20 \pm 2{ }^{\circ} \mathrm{C}$ and TMP of 0.5 (for MF) and 2.0 bar (for UF). The effect of TMP (0.05-1.0 bar) and CFV (1.6-2.5 m.s $\left.\mathrm{s}^{-1}\right)$ on permeate flux in total recycle mode were studied using the best membrane pore size or MWCO obtained from the previous experiment. The optimum condition 
obtained was then employed for clarification and sterilization of coconut water under batch concentration (retentate was returned to the feed tank). Note that \% recovery was defined as the percentage of permeate volume to initial feed volume.

\subsection{Fouling Resistance Analysis}

The membrane filtration process can generally be described by Darcy's law as follow:

$$
J=\frac{T M P}{\mu R_{t}}
$$

where $J(\mathrm{~m} / \mathrm{s})$ is the permeation flux, TMP is the transmembrane pressure ( $\mathrm{kPa}), \mu$ (Pa.s) is the viscosity of the permeate and $R_{t}(1 / \mathrm{m})$ is the total resistance to the permeate. $R_{t}$ could be classified by equation (2) as follow:

$$
\begin{aligned}
& R_{t}=R_{m}+R_{r f}+R_{i f} \\
& R_{i f}=R_{i f-i n}+R_{i f-e x}
\end{aligned}
$$

In equation (2), $R_{t}$ is the sum of $R_{m}$ (membrane resistance), $R_{r f}$ (the resistance caused by reversible fouling) and $R_{i f}$ (the resistance caused by irreversible fouling). Furthermore, $R_{i f}$ could be divided into two types, resistance caused by internal irreversible fouling $\left(R_{i f-i n}\right)$ and external irreversible fouling $\left(R_{i f-e x}\right)$ (equation (3)). In this study, reversible fouling was defined as the fouling which could be removed by only water flushing. The residual fouling after water flushing was irreversible fouling and it was further cleaned by chemical cleaning. The resistance defined by equation (2) and (3) could be evaluated by measurement of water flux during cleaning process which is a cleaning in place method (CIP). $R_{m}$ was determined by measurement of water flux of clean membrane. After filtration of coconut water, the water was flushed through the membrane surface to removed reversible fouling while permeate valve was closed. Water flushing was operated using clean water at CFV of $1.35 \mathrm{~m} / \mathrm{s}$ and TMP of 0.3 bar for 15 minutes. After the first water flushing, the permeate valve was opened and water flux was measured to determined residual fouling resistance (i.e., $R_{m}+R_{i f}$ ). Then permeate valve was closed again. A chemical cleaning was applied by circulating $0.5 \mathrm{~N} \mathrm{NaOH}$ solution at $50^{\circ} \mathrm{C}$, TMP 0.3 bar and CFV $1.35 \mathrm{~m} / \mathrm{s}$ for 40 minutes to remove external irreversible fouling. After that the chemical cleaning solution was removed by water flushing. Then the water flux was measured to evaluated residual resistance (i.e. $R_{m}+R_{i f-i n}$ ). After that the internal irreversible fouling was removed by circulating $50 \mathrm{ppm}$ of $\mathrm{NaOCl}$ at $50^{\circ} \mathrm{C}$, TMP $0.3 \mathrm{bar}$ and CFV $1.35 \mathrm{~m} / \mathrm{s}$ for at least 40 minutes while the permeate valve open. With $R_{t}$ obtained after filtration of coconut water and using from equation (1) and the results from cleaning procedure combining with equation (2) and (3), all types of resistances could be worked out.

\subsection{Fresh and Clarified Coconut Water Analysis}

Samples of fresh coconut water (feed) and clarified coconut water from both MF and UF operation were collected for further analysis. The $\mathrm{pH}$ and total soluble solid were analyzed by using $\mathrm{pH}$ meter (PP15, Sartorius, Germany) and hand refractometer (2311, Atago, Japan) respectively. The acidity (expressed as citric acid equivalent) was analyzed by titration method (titration of 10 $\mathrm{ml}$ of sample with $0.1 \mathrm{~N} \mathrm{NaOH}$ to an endpoint at $\mathrm{pH}$ 8.1). The total sugar and reducing sugar were determined by the method of AOAC [6]. The color was measured by colorimeter (Color Quest XT, Hunter Lab, USA). The viscosity was measured at $20^{\circ} \mathrm{C}$ with u-tube capillary viscometer (Kapillarviskosimeter 50904, Schott, Germany). Protein content was determined by Lowry method [7]. Microbiological analyses of the sample was performed by the methodology described in Bacteriological Analytical Manual (BAM) [8]. The content of estradiol (estrogen hormone) was analyzed using CELIA method (electro generated chemiluminescence immuno assay). The minerals content including sodium, calcium, magnesium, phosphorus and potassium were determined by using the inductively coupled plasma - optical emission spectrometer (ICPOES). 


\subsection{RESULTS AND DISCUSSION}

\subsection{Chemical and Physical Properties of Fresh and Clarified Coconut Water}

Properties of fresh coconut water and clarified coconut water using various membranes are shown in Table 1. The chemical and physical properties of clarified coconut water did not show difference in $\mathrm{pH}$, total soluble solid, reducing sugar and density comparing to fresh coconut water. The viscosity of clarified coconut water was lower than that of fresh coconut water. However, the total solid and total sugars were slightly decreased as membrane pore size and MWCO decreased. It was also found that the highest of luminosity ( $\mathrm{L}$ - value) of fresh coconut water was observed followed by MF-clarified coconut water and UF-clarified coconut water, indicating that clearer and brighter coconut water was obtained after membrane filtration. Protein content in fresh coconut water was $1.069 \pm 0.032 \mathrm{mg} / 100 \mathrm{ml}$. The protein content in clarified coconut water using $0.2 \mu \mathrm{m}$ membrane showed no significant difference compared to that in fresh coconut water. The membrane having a larger pore size or MWCO tend to give the higher protein content or lower protein rejection. It is also important to note that this protein rejection characteristic probably involved in fouling behavior.

\subsection{Mineral and Estrogen Hormone Content in Fresh and Clarified Coconut Water}

One of the primary aims of this study was to investigate the effect of membrane pore size an MWCO on clarified coconut water quality. Estrogen hormone and minerals are important components in coconut water. Table 2 shows the estradiol (estrogen hormone) and minerals content including calcium, magnesium, phosphorus, potassium and sodium in coconut water before and after membrane filtration. The results show that there were no significant difference in the content of mineral and estrogen hormone between fresh and clarified coconut water. The result indicated that minerals and estrogen hormone could be preserved or recovered with

Table 1 Chemical and physical properties of coconut water before and after membrane filtration with various membrane pore size and MWCO

\begin{tabular}{|c|c|c|c|c|c|}
\hline Properties & $\begin{array}{l}\text { Fresh } \\
\text { Coconut } \\
\text { water }\end{array}$ & $\begin{array}{l}\text { Clarified } \\
\text { from } \\
0.2 \mu \mathrm{m}\end{array}$ & $\begin{array}{l}\text { Clarified } \\
\text { from } \\
0.1 \mu \mathrm{m}\end{array}$ & $\begin{array}{l}\text { Clarified } \\
\text { from } \\
100 \mathrm{kDa}\end{array}$ & $\begin{array}{l}\text { Clarified } \\
\text { from } \\
30 \mathrm{kDa}\end{array}$ \\
\hline Total solid (\%) & $9.32 \pm 0.06^{\mathrm{a}}$ & $7.17 \pm 0.07^{b}$ & $7.20 \pm 0.07^{b}$ & $6.50 \pm 0.20^{c}$ & $6.87 \pm 0.14^{\mathrm{d}}$ \\
\hline Total sugar (\%) & $6.03 \pm 0.15^{\mathrm{a}}$ & $5.48 \pm 0.22^{b}$ & $5.29 \pm 0.21^{\mathrm{bc}}$ & $4.17 \pm 0.22^{\mathrm{c}}$ & $5.09 \pm 0.13^{\mathrm{d}}$ \\
\hline Reducing sugar (\%) & $4.37 \pm 0.48^{\text {ns }}$ & $4.39 \pm 0.39^{\text {ns }}$ & $4.17 \pm 0.22^{\mathrm{ns}}$ & $4.04 \pm 0.14^{\mathrm{ns}}$ & $4.12 \pm 0.09^{\mathrm{ns}}$ \\
\hline \multicolumn{6}{|l|}{ Total soluble solid } \\
\hline$\left({ }^{\circ}\right.$ Brix $)$ & $6.83 \pm 0.15^{\mathrm{ns}}$ & $6.80 \pm 0.1^{\mathrm{ns}}$ & $6.9 \pm 0.1^{\mathrm{ns}}$ & $6.9 \pm 0.1^{\mathrm{ns}}$ & $6.83 \pm 0.05^{\mathrm{ns}}$ \\
\hline $\mathrm{pH}$ & $5.30 \pm 0.15^{\mathrm{ns}}$ & $5.35 \pm 0.13^{\mathrm{ns}}$ & $5.41 \pm 0.16^{\mathrm{ns}}$ & $5.29 \pm 0.01^{\mathrm{ns}}$ & $5.19 \pm 0.04^{\mathrm{ns}}$ \\
\hline \multicolumn{6}{|l|}{ Acidity ( $\%$ as citric } \\
\hline $\begin{array}{l}\text { acid) } \\
\text { Viscosity (mPa.S) }\end{array}$ & $\begin{array}{l}0.053 \pm 0.005 \\
0.0119 \pm 0.001^{\mathrm{a}}\end{array}$ & $0.0114 \pm 0.000^{b}$ & $0.0114 \pm 0.000^{\mathrm{b}}$ & $0.0114 \pm 0.000^{\mathrm{b}}$ & $0.0113 \pm 0.000^{b}$ \\
\hline Density $\left(\mathrm{Kg} / \mathrm{m}^{3}\right)$ & $993.1 \pm 8.6^{\mathrm{ns}}$ & $1001.3 \pm 5.13^{\text {ns }}$ & $999.2 \pm 9.6^{\mathrm{ns}}$ & $994.3 \pm 7.85^{\text {ns }}$ & $003.5 \pm 4.44^{\mathrm{ns}}$ \\
\hline \multicolumn{6}{|l|}{ Color } \\
\hline $\mathrm{L}^{*}$ & $101.27 \pm 0.39^{c}$ & $102.28 \pm 0.21^{b}$ & $102.38 \pm 0.08^{b}$ & $103.48 \pm 0.13^{\mathrm{a}}$ & $103.49 \pm 0.25^{\mathrm{a}}$ \\
\hline$a^{*}$ & $-0.19 \pm 0.06^{\mathrm{ns}}$ & $-0.18 \pm 0.04^{\mathrm{ns}}$ & $-0.06 \pm 0.24^{\mathrm{ns}}$ & $-0.06 \pm 0.24^{\mathrm{ns}}$ & $0.203 \pm 0.10^{\mathrm{ns}}$ \\
\hline $\mathrm{b}^{*}$ & $0.74 \pm 0.06^{\mathrm{a}}$ & $0.11 \pm 0.07^{\mathrm{b}}$ & $0.096 \pm 0.005^{b}$ & $-0.15 \pm 0.08^{\mathrm{d}}$ & $-0.02 \pm 0.05^{\mathrm{c}}$ \\
\hline Protein $(\mathrm{mg} / 100 \mathrm{ml})$ & $1.069 \pm 0.032^{\mathrm{a}}$ & $0.707 \pm 0.269^{\mathrm{a}}$ & $0.544 \pm 0.013^{b}$ & $0.386 \pm 0.052^{\mathrm{bc}}$ & $0.149 \pm 0.019^{c}$ \\
\hline
\end{tabular}

Same letters in the same row present no statistical differences according to Duncan's multiple range test at $\mathrm{P}<0.05$ 
Table 2 Estrogen hormone (estradiol) and minerals content in fresh and clarified coconut water with various membranes

\begin{tabular}{|c|c|c|c|c|c|}
\hline Properties & $\begin{array}{l}\text { Fresh } \\
\text { Coconut } \\
\text { water }\end{array}$ & $\begin{array}{l}\text { Clarified } \\
\text { from } \\
0.2 \mu \mathrm{m}\end{array}$ & $\begin{array}{l}\text { Clarified } \\
\text { from } \\
0.1 \mu \mathrm{m}\end{array}$ & $\begin{array}{l}\text { Clarified } \\
\text { from } \\
100 \mathrm{kDa}\end{array}$ & $\begin{array}{l}\text { Clarified } \\
\text { from } \\
30 \mathrm{kDa}\end{array}$ \\
\hline Estradiol (pg/ml) & $30.55 \pm 1.88^{\text {ns }}$ & $27.46 \pm 1.27^{\mathrm{ns}}$ & $29.15 \pm 2.49^{\mathrm{ns}}$ & $28.78 \pm 2.66^{\mathrm{ns}}$ & $27.90 \pm 0.87^{\mathrm{ns}}$ \\
\hline \multicolumn{6}{|l|}{ Minerals } \\
\hline Phosphorus (mg/l) & $66.20 \pm 7.88^{\mathrm{ab}}$ & $57.62 \pm 1.50^{\mathrm{a}}$ & $57.77 \pm 5.68^{\mathrm{a}}$ & $67.50 \pm 2.19^{b}$ & $68.38 \pm 4.30^{\mathrm{ab}}$ \\
\hline Potassium $(\mathrm{g} / \mathrm{l})$ & $1.15 \pm 0.01^{\mathrm{ns}}$ & $0.98 \pm 0.17^{\mathrm{ns}}$ & $1.03 \pm 0.05^{\mathrm{ns}}$ & $1.15 \pm 0.01^{\mathrm{ns}}$ & $1.13 \pm 0.02^{\mathrm{ns}}$ \\
\hline Calcium $(\mathrm{g} / \mathrm{l})$ & $0.143 \pm 0.020^{\mathrm{ns}}$ & $0.123 \pm 0.037^{\mathrm{ns}}$ & $0.123 \pm 0.020^{\mathrm{ns}}$ & $0.143 \pm 0.020^{\mathrm{ns}}$ & $0.140 \pm 0.026^{\text {ns }}$ \\
\hline Magnesium ( $\mathrm{g} / \mathrm{l})$ & $64.86 \pm 4.93^{\mathrm{ns}}$ & $57.93 \pm 12.00^{\mathrm{ns}}$ & $57.26 \pm 3.55^{\mathrm{ns}}$ & $64.46 \pm 7.34^{\mathrm{ns}}$ & $63.40 \pm 6.77^{\mathrm{ns}}$ \\
\hline Sodium $(g / 1)$ & $38.66 \pm 4.50^{\mathrm{ns}}$ & $37.60 \pm 2.95^{\mathrm{ns}}$ & $38.26 \pm 4.27^{\mathrm{ns}}$ & $36.86 \pm 7.00^{\mathrm{ns}}$ & $46.73 \pm 6.01^{\mathrm{ns}}$ \\
\hline
\end{tabular}

Same letters in the same row present no statistical differences according to Duncan's multiple range test at $\mathrm{P}<0.05$

membrane filtration process. The reason is probably due to the fact that estrogen hormone and minerals have low molecular weight $(\mathrm{MW}=$ 272.39 for estrogen [9]). Therefore, it was freely passed through membranes.

\subsection{Microbiological Quality of Fresh and Clarified Coconut Water}

The microbiological quality of coconut water before and after membrane filtration is presented in Table 3. It was found that no yeast, mould and E. Coli found in fresh coconut water. Total variable count of fresh coconut water was relatively low $(77 \mathrm{CFU} / \mathrm{ml})$ and it was completely removed by MF and UF. The microbiological quality was met to the Thai legislation for juice and drinks. These results indicated that membrane filtration could be employed for sterilization of coconut water.

\subsection{Permeate Flux and Membrane Fouling}

\subsubsection{Effect of Membrane Pore Size and MWCO}

The permeate flux during MF and UF of coconut water in total recycle mode was shown in Figure 1. The permeate flux of four membranes rapidly declined in the initial state of filtration. The higher initial permeate flux was observed from the larger pore size (for MF) or higher MWCO (for UF) membranes. For MF process, although the initial permeate flux of $0.2 \mu \mathrm{m}$ membrane was higher than that of $0.1 \mu \mathrm{m}$ membrane (at TMP 0.5 bar) but it was more rapidly declined compared to that of $0.1 \mu \mathrm{m}$ membrane. The steady permeate fluxes of 0.2 and $0.1 \mu \mathrm{m}$ membranes were reached after filtration time of 1 hour at about 199 and $190 \mathrm{l} / \mathrm{m}^{2} \mathrm{~h}$ respectively. In UF process, the initial permeate flux of $100 \mathrm{kDa}$ was higher than that of $30 \mathrm{kDa}$ (at TMP $2.0 \mathrm{bar}$ ). The permeate flux

Table 3 Microbiological quality of fresh and clarified coconut water obtained from various membrane pore size and MWCO

\begin{tabular}{|c|c|c|c|c|c|}
\hline Microbiology & $\begin{array}{l}\text { Fresh } \\
\text { Coconut } \\
\text { water }\end{array}$ & $\begin{array}{l}\text { Clarified } \\
\text { from } \\
0.2 \mu \mathrm{m}\end{array}$ & $\begin{array}{l}\text { Clarified } \\
\text { from } \\
0.1 \mu \mathrm{m}\end{array}$ & $\begin{array}{l}\text { Clarified } \\
\text { from } \\
100 \mathrm{kDa}\end{array}$ & $\begin{array}{l}\text { Clarified } \\
\text { from } \\
30 \mathrm{kDa}\end{array}$ \\
\hline Total plate count (CFU/ml) & $77 \pm 27$ & 0 & 0 & 0 & 0 \\
\hline Yeast and mould (CFU/ml) & 0 & 0 & 0 & 0 & 0 \\
\hline E.Coli $(\mathrm{MPN} / \mathrm{ml})$ & $<3$ & $<3$ & $<3$ & $<3$ & $<3$ \\
\hline
\end{tabular}

Same letters in the same row present no statistical differences according to Duncan's multiple range test at $\mathrm{P}<0.05$ 


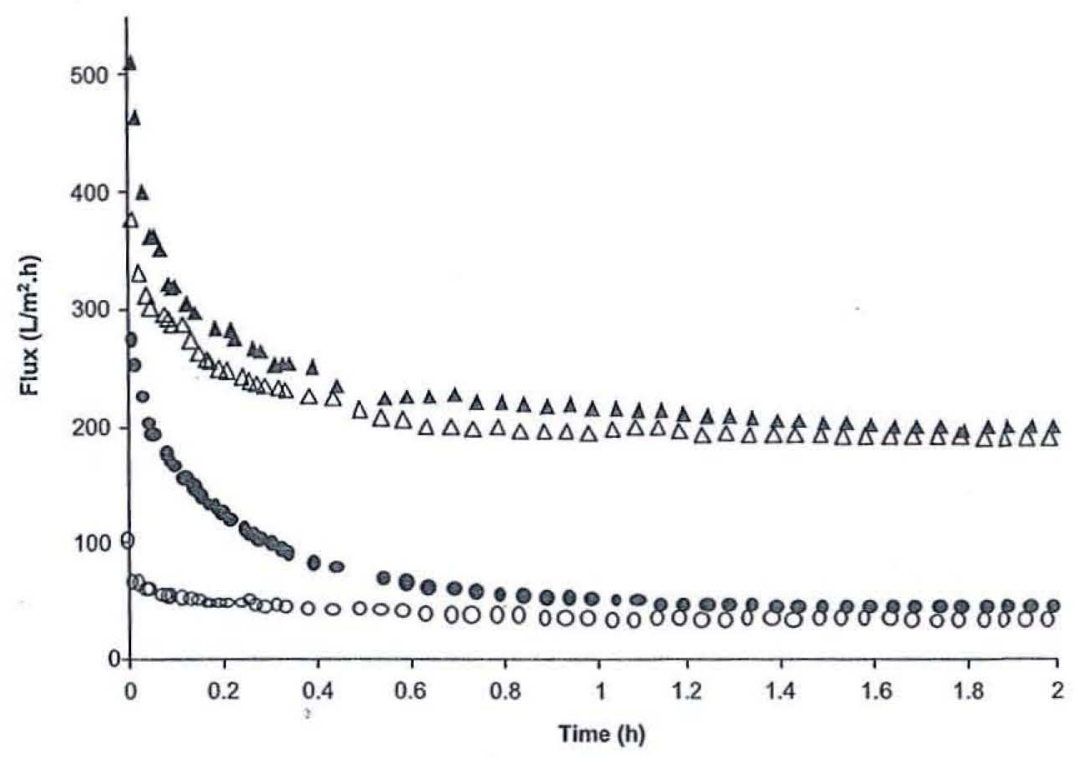

Figure 1 Permeate flux during membrane filtration of coconut water $(\Delta, 0.2 \mu \mathrm{m}, \Delta 0.1 \mu \mathrm{m}, \odot 100$ $\mathrm{kDa}, \mathrm{O} 30 \mathrm{kDa}$ ) at $\mathrm{CFV}=1.18 \mathrm{~m} / \mathrm{s}$, temperature $=20 \pm 2^{\circ} \mathrm{C}$, TMP $=0.5$ bar for $\mathrm{MF}$ and $\mathrm{TMP}=2.0 \mathrm{bar}$ for $\mathrm{UF}$

of $100 \mathrm{kDa}$ membrane declined to the steady state after the filtration time about 1 hour (at $45 \mathrm{l} / \mathrm{m}^{2} \mathrm{~h}$ ) while steady state flux of $30 \mathrm{kDa}$ membrane was reached after filtration time about 30 minutes (at $32 \mathrm{l} / \mathrm{m}^{2} \mathrm{~h}$ ). The declined of permeate flux could be due to fouling and concentration polarization. The major fouling materials during MF and UF of coconut water would be the suspended solid, fat, protein and other small molecules. Membrane fouling during MF and UF could be formed on the top of membrane surface and/or inside the membrane pore [10]. The difference in the rate of flux decline and filtration time to reach steady flux suggested the effect of membrane pore size or MWCO on membrane fouling and possibly fouling mechanism.
Table 4 shows the $R_{m}, R_{t}, R_{r f}$ and $R_{i f}$ that was divided to two types i.e. $R_{i f-\text { in }}$ and $R_{i f-e x}$. $R_{t}$ of $0.2 \mu \mathrm{m}, 0.1 \mu \mathrm{m}, 100 \mathrm{kDa}$ and $30 \mathrm{kDa}$ membrane were $7.89 \times 10^{11}, 8.36 \times 10^{11}, 142.43 \times 10^{11}$ and $191.59 \times 10^{11} 1 / \mathrm{m}$ respectively. It could be observed that the $R_{t}$ of MF membrane were lower than those of UF membrane and about 40-60\% of $R_{t}$ of both MF and UF membranes was contributed by $R_{r f}$. The reason could be due to the different in $R_{m}$ and operating TMP during membrane filtration process $(0.5$ bar for MF and 2 bar for UF) which induced the $R_{r f}$ and compression of gel layer on the membrane surface[11]. For irreversible fouling, the $R_{i f}$ of MF membrane was much lower than that of UF membrane and most of $R_{i f}$ of both MF and UF membranes was con-

Table 4 Permeate resistances during membrane filtration of coconut water

\begin{tabular}{|c|c|c|c|c|c|c|}
\hline Membrane & $\begin{array}{c}R_{m}\left(\times 10^{11}\right) \\
1 / \mathrm{m}\end{array}$ & $\underset{1 / \mathrm{m}}{R_{t}\left(\times 10^{11}\right)}$ & $\begin{array}{c}R_{r f}\left(\times 10^{11}\right) \\
1 / \mathrm{m}\end{array}$ & $\begin{array}{c}R_{i f}\left(\times 10^{11}\right) \\
1 / \mathrm{m}\end{array}$ & $\begin{array}{c}R_{i f-\mathrm{ex}}\left(\times 10^{11}\right) \\
1 / \mathrm{m}\end{array}$ & $\begin{array}{c}R_{i f-i n}\left(\times 10^{11}\right) \\
1 / \mathrm{m}\end{array}$ \\
\hline $0.2 \mu \mathrm{m}$ & 0.69 & 7.98 & 4.82 & 2.25 & 2.35 & 0.11 \\
\hline $0.1 \mu \mathrm{m}$ & 2.38 & 8.36 & 4.9 & 1.08 & 0.83 & 0.15 \\
\hline $100 \mathrm{kDa}$ & 13.0 & 142.32 & 122.77 & 6.05 & 5.65 & 0.4 \\
\hline $30 \mathrm{kDa}$ & 48.0 & 191.59 & 95.8 & 44.84 & 43.14 & 1.70 \\
\hline
\end{tabular}


tributed by $R_{i f-e x}$. In addition, the $R_{i f-e x}$ of $0.2 \mu \mathrm{m}$ membrane was much higher than that of $0.1 \mu \mathrm{m}$ membrane while the $R_{\text {if-ex }}$ of $100 \mathrm{kDa}$ membrane was much lower than that of $30 \mathrm{kDa}$ membrane. The $R_{i f-\text { in }}$ of UF membrane was higher than those of MF membrane. The $R_{i f-\text { in }}$ of 0.1 and $0.2 \mu \mathrm{m}$ membranes did not significantly different. For UF, the $R_{i f-i n}$ of $30 \mathrm{kDa}$ membrane was about 4 times higher than that of $100 \mathrm{kDa}$ membrane. These results suggested that both suspended solid and protein was possibly responsible for internal fouling of the MF membrane while protein and other small molecules played an important role in internal fouling of UF membrane.

From these results, $0.2 \mu \mathrm{m}$ membrane gave the highest permeate flux followed by $0.1 \mu \mathrm{m}, 100$ $\mathrm{kDa}$ and $30 \mathrm{kDa}$ membranes respectively. However, the irreversible fouling resistance of $0.1 \mu \mathrm{m}$ membrane was the lowest. In addition, the quality of clarified coconut water obtained from both MF and UF membrane did not significantly different. According to these results, $0.1 \mu \mathrm{m}$ membrane was considered to be the most suitable membrane for sterilization of coconut water.

\subsubsection{Effect of TMP and CFV on Permeate Flux}

MF with $0.1 \mu \mathrm{m}$ membrane was used for studying on the effect of TMP and CFV during membrane filtration in total recycle mode. Figure 2 shows the effect of TMP on steady flux at constant CFV of $2.5 \mathrm{~m} / \mathrm{s}$. It was found that the pressure dependent region was obtained at TMP below $0.65 \mathrm{bar}$, giving the limiting flux of about 178 $1 / \mathrm{m}^{2} \mathrm{~h}$. Further increase in TMP higher than 0.65 bar didn't result in continuously increased in permeate flux and sever fouling at this pressure independent region was expected [11]. To avoid the sever fouling in this case, operating at TMP below 0.65 bar (at CFV $2.5 \mathrm{~m} / \mathrm{s}$ ) was suggested. Figure 3 shows the steady permeate flux at difference $\mathrm{CFV}$ using TMP at 0.65 bar. The result showed that the permeate flux significantly increased as $\mathrm{CFV}$ increased. Similar explanation for this phenomenon has been given. At high CFV, the rate of removal of retained material by high shear force is high and would reduce reversible fouling and enhance the mass transfer rate that benefits permeate flux $[12,13]$.

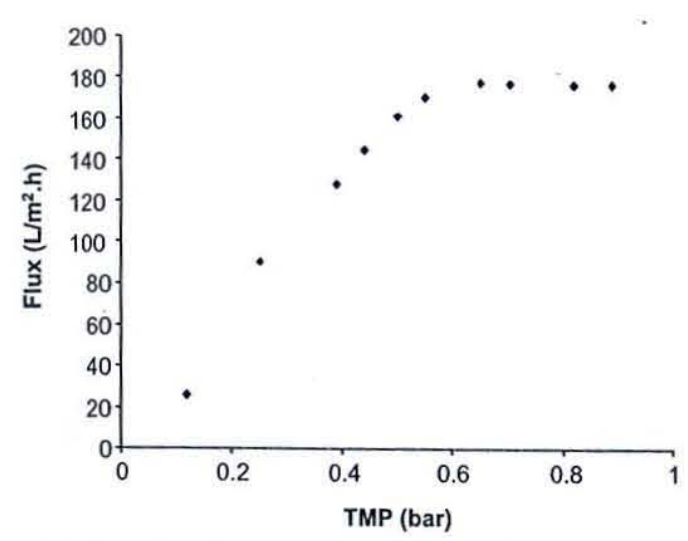

Figure 2 Effect of TMP on the permeate flux (membrane pore size $0.1 \mu \mathrm{m}, \mathrm{CFV}=$ $2.5 \mathrm{~m} / \mathrm{s}$, temperature $=20 \pm 2\left({ }^{\circ} \mathrm{C}\right)$

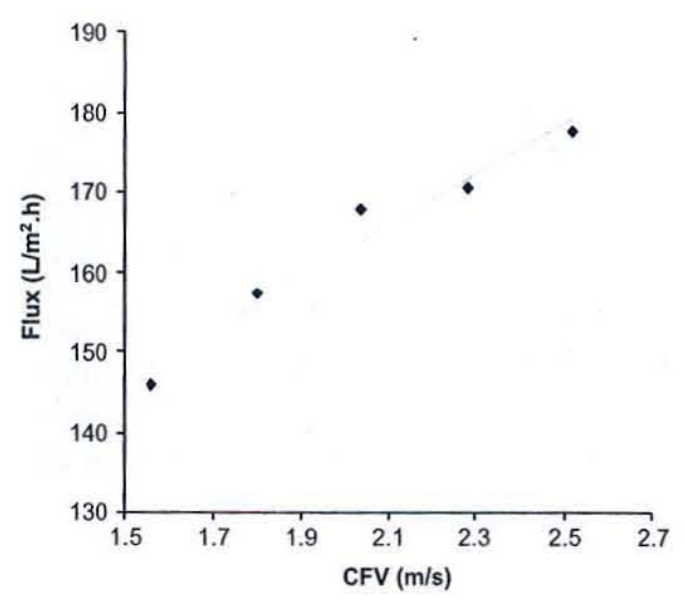

Figure 3 Effect of feed cross flow velocity on the steady state permeate flux 0.65 bar (membrane pore size $0.1 \mu \mathrm{m}$ TMP $=$ $0.65 \mathrm{bar}$, temperature $=20 \pm\left({ }^{\circ} \mathrm{C}\right)$

\subsubsection{Permeate Flux in Batch Concentration Mode}

Figure 4 shows the permeate flux versus filtration time during MF using $0.1 \mu \mathrm{m}$ membrane pore size in batch concentration mode. The permeate flux was sharply decreased in initial five minutes of the filtration time. After that the flux gradually deceased until the end of process (at 25 minutes). The permeate flux at the end of the process was about $148 \mathrm{l} / \mathrm{m}^{2} \mathrm{~h}$ which is lower than that obtained 


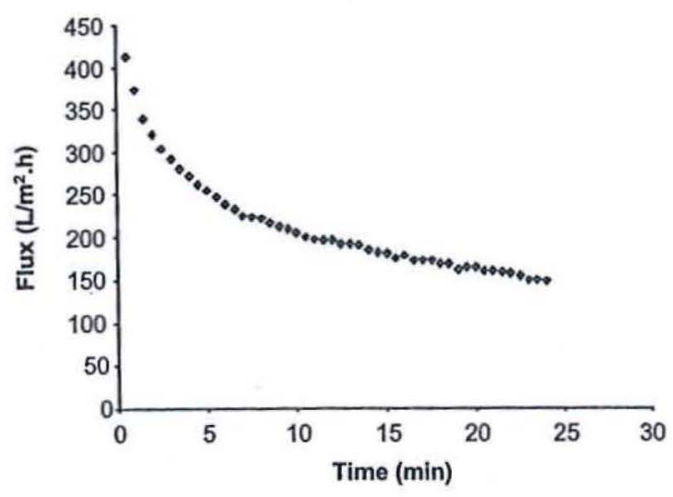

Figure 4 Permeate flux profile during MF of coconut water with batch concentration mode (membrane pore size $0.1 \mu \mathrm{m}$, cross flow velocity $=2.5 \mathrm{~m} / \mathrm{s}$, TMP $=$ 0.65 bar, temperature $=20 \pm 2^{\circ} \mathrm{C}$ )

from $0.1 \mu \mathrm{m}$ membrane with total recycle mode in the section 3.4.1 at the same operation time. The reason could be due to membrane fouling and an increasing in feed viscosity and concentration of rejected suspended solid particles during batch concentration mode. The permeate flux behavior versus \% recovery using the data from the same experiment was shown in Figure 5 . About $88 \%$ recovery was obtained at filtration of 25 minutes. The average of permeate flux was about $200 \mathrm{l} / \mathrm{m}^{2} \mathrm{~h}$.

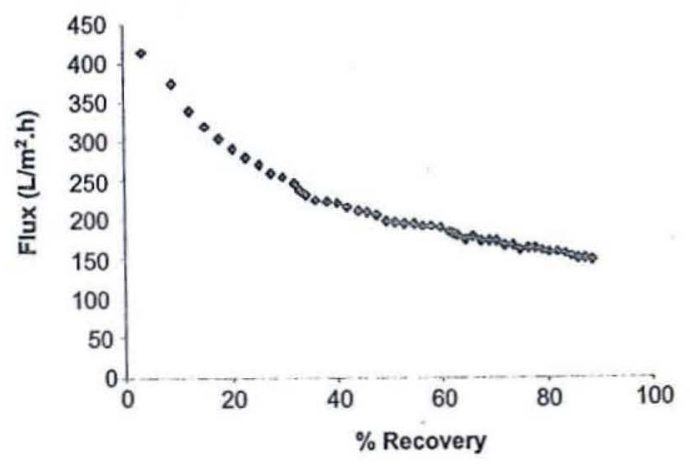

Figure $5 \%$ Recovery versus permeate flux with batch concentration mode (membrane pore size $0.1 \mu \mathrm{m}, \mathrm{CFV}=2.5 \mathrm{~m} / \mathrm{s}$, TMP $=0.65 \mathrm{bar}$, temperature $=20 \pm 2^{\circ} \mathrm{C}$ )

\subsection{CONCLUSION}

The fresh coconut water was successfully clarified and sterilized by either MF or UF membrane. The membrane pore size and MWCO did not affect the quality of clarified coconut water and the contents of minerals and estrogen hormone in clarified coconut water were closed to those found in fresh coconut water. The result from microbiological analysis indicated that clarified coconut water of MF and UF were microorganismfree (sterilized). The major fouling of both MF and UF were reversible. Both reversible and irreversible fouling resistances of UF membrane were much higher than those of MF membrane. The permeate flux of $0.1 \mu \mathrm{m}$ was slightly lower than that of $0.2 \mu \mathrm{m}$ membrane while the irreversible fouling resistance of $0.1 \mu \mathrm{m}$ membrane was much lower than that of $0.2 \mu \mathrm{m}$ membrane. According to these results, membrane with $0.1 \mu \mathrm{m}$ pore size was considered to be the most suitable membrane for clarification and sterilization of coconut water. The permeate flux was increased dramatically with increasing CFV and decreased as feed concentration or \% recovery increased. The result suggested that the permeate flux during of coconut water could be improved using hydrodynamic modification technique.

\section{ACKNOWLEDGEMENTS}

The authors would like to thank the Faculty of Agro-Industry and Graduate School, Prince of Songkla University and National Center for Genetic Engineering and Biotechnology (BIOTEC) of Thailand (Project code BT-B-01FG-18-5003) for financial support.

\section{REFERENCES}

[1] New Sport Drink, Coconut Water. http:// www.fao.org/AG/magazine/9810/ spot3.htm (20 March 2007).

[2] Coconut Research Center, The Tree of Life. http://www.coconutresearchcenter.org/ (19 March 2007). 
[3] Monk, D., and H. Brodaty. 2000. Use of Estrogen for the Prevention and Treatment of Alzizherimer's Disease. Dement Geriatr Cogn Disord. 11: 1-10.

[4] Radenahmad, N., U. Vongvatcharanon, E. Withyachumnarnkul, and J. Connor. 2006. Serum Levels of $17 \beta$-estradiol in Ovariecto-mized Rats Fed Young-coconutjuice and its Effect on Wound Healing. Songklanakarin. J. Sci. Technol. 28(5): 897909.

[5] Girard, B. and L.R. Fukumoto. 2000. Membrane Processing of Fruit Juice and Beverage: A Review. Crit. Rev. Food Sci. Nutr. 40(2): 91-157.

[6] AOAC. 2000. In: Cunnif, P. (Ed). Official Methods of Analysis of AOAC. International. $17^{\text {th }}$ ed. AOAC International. Alrington, VA.

[7] Lowry, O.H., N.J. Rosebrough, A.L. Farr, and R.J. Randall. 1951. Protein Measurement with Folin Phenolragent. Journal of Biochemistry. 193: 265-275.

[8] Bacteriological Analytical Manual Online, 2002. US. Food and Drag Administration. <available from: http://www.cfsan.fda.gov/ $\sim$ ebam/bam-4.html>

[9] Zhu, Q., L. Wang, S. Wu, J. Wasswa, W. Joseph, X. Gu, and J. Tang. 2009. Selectivity of Moleculary Imprinted Solid Phase Extraction for Sterol Compounds. J. Food. Chem. 113: 608-615.

[10] Youravong, W., M. Phukdeekhong, and P. Taksinpatahapong. 2005. Influence of Membrane Properties on Pineapple Wine Clarification and Fouling Behaviour. Applied Membrane Sci.\& Tech.1: 8-18.

[11] Youn, K.S., J.H. Houng, D.H. Bae, S.J. Kim, and S.D. Kim. 2004. Effective Clarifying Process of Reconstituted Apple Juice using Membrane Filtration with Filter-aid Pretreatment. J. Membr. Sci. 228: 179-186.

[12] Wu, D., J.A. Howell, and R.W. Field. 1999. Critical Flux Measurement for Model Colloids. J. Membr. Sci. 152: 89-98.

[13] Jiraratananon, R., and A. Chanachai. 1996. A Study of Fouling in the Ultrafiltration of Passion Fruit Juice. J. Membr. Sci. 111: 39. 